\title{
Effect of Processing on the Physico-Chemical Properties and Yield of Gari from Dried Chips
}

\author{
Udoro Elohor Oghenechavwuko*, Gbadamosi Olasunkanmi Saka, Taiwo Kehinde Adekunbi and Akanbi Charles Taiwo
}

Department of Food Science and Technology, Obafemi Awolowo University, Ile-Ife, Osun State, Nigeria

\begin{abstract}
Fresh cassava tubers of the bitter variety (Manihot esculenta Crantz) were processed into dried chips (sun and oven drying at 50 and $70^{\circ} \mathrm{C}$ ). The proximate composition, physico-chemical properties, cyanide content and water absorption capacity of the chips were determined. The chips were milled and soaked in four day old liquor (4DOL) for 3 or 4 days, and pressed for 3 or 2 'days, respectively. The pressed mash was sieved, fried, cooled and packaged. The $\mathrm{pH}$ and titratable acidity (TTA) of the soaking medium was determined at $24 \mathrm{~h}$ interval during soaking of chips. Gari samples from dried chips and from fresh tubers were analyzed for yield.

The results showed that moisture content $(10.24 \%)$ of chips dried at $70^{\circ} \mathrm{C}$ was significantly $(p<0.05)$ lower than that of sun dried and $50^{\circ} \mathrm{C}$ oven dried chips. The ash (1.53-2.06\%), protein (1.30-2.56\%), crude fat (1.34-1.47\%), crude fiber $(2.58-2.72 \%)$ and carbohydrate $(79.21-82.08 \%)$ contents were not significantly $(p<0.05)$ different among the samples. The cyanide content of the chips ranged between $58.26-69.83 \mathrm{mg} / 100 \mathrm{~g}$, sun dried chips had the least cyanide content. Water absorption capacity $(28.21-98.81 \%)$ of chips increased with time with chips dried at $50^{\circ} \mathrm{C}$ having the highest value after $6 \mathrm{~h}$ of soaking. The $\mathrm{pH}(4.65-3.90)$ of the medium decreased while the TTA $(0.09-0.68)$ increased during fermentation. The yields of gari increased with soaking time and the values $(71-78 \%)$ obtained were comparable to those in literature.
\end{abstract}

Keywords: Dried cassava chips; Gari; Water absorption capacity; Fermentation; Physico-chemical properties; Proximate composition

\section{Introduction}

Cassava (Manihot esculenta Crantz) belongs to the family Euphorbiaceae. It is a perennial woody shrub producing enlarged tuberous roots. Cassava in fresh form contains cyanide; it is highly perishable and cannot be stored for more than a few days after harvesting. Cyanide is extremely toxic to humans and animals, therefore the roots need to be processed to reduce the cyanide content to safe levels before consumption $[1,2]$. Dehydrated chips are unfermented dried products of cassava. Drying is widely practised to improve the shelf life of the tuber and also helps in the process of detoxification $[3,4]$.

Drying of cassava is widely practised to reduce post-harvest losses. The roots, after peeling and washing, are chipped into smaller sizes for faster drying. Drying is done naturally in the sun or artificially in the oven at controlled temperatures. Chips are mostly used in the production of starch and animal feeds even though it has potentials for human consumption. The need to expand the utilization base of dried cassava chips has prompted different workers to carry out studies on the utilization/conversion of cassava chips to various food products such as; gari, fufu, and lafun for human consumption [4-6].

Gari is a fermented cassava product and is one of the major products obtained from cassava in the West African sub region $[1,7]$. Studies have shown that gari can also be obtained from cassava chips by seeding it with some of the fresh root [6] and by soaking in old liquor [8]. However not much has been reported on the effect of processing variables on the quality of chips (physico-chemical properties) and the yield of gari obtained from the chips. The objective of this work, therefore, is to provide information on i) the effect of drying temperatures on the proximate composition, physico-chemical properties and water absorption capacity of chips, ii) the influence of soaking and pressing times on the yield and sensory characteristics of the resulting gari from the chips. This is with a view to establishing a processing method that will give a good yield of gari having acceptable quality from the dried cassava chips.

\section{Materials and Methods}

\section{Materials}

Bitter variety (Manihot esculenta Crantz) of freshly harvested cassava tubers (10-12 months old) were purchased from the University Teaching and Research Farm on Obafemi Awolowo University Campus, Ile-Ife. All chemicals used were of analytical grade.

\section{Preparation of dried cassava chips}

The method described by [3] was used with slight modifications in preparing the chips. The freshly harvested cassava tubers were sorted to remove bruised or rotten tubers and then washed with water to remove extraneous materials such as plant debris, stones, sand and dirt. The washed cassava tubers were weighed, manually peeled using a sharp knife and weighed again. The peeled tubers were sliced manually into chips of $2.0 \pm 1.0 \mathrm{~cm}$ thickness using a sharp knife and a vernier calliper. The sliced cassava chips were divided into three parts. The first part was sun dried by spreading the slices on perforated stainless steel trays and left in the sun $\left(32^{\circ} \mathrm{C} \pm 2^{\circ} \mathrm{C}\right.$, relative humidity $\left.55 \%\right)$ until the chips were dried (an average of 3 days). The second and third parts were dried in the oven (DK-500WT, MRC LTD, Israel) at $50^{\circ} \mathrm{C}$ and

*Corresponding author: Udoro Elohor Oghenechavwuko, Department of Food Science and Technology, Obafemi Awolowo University, Ile-Ife, Osun State, Nigeria, Tel: +234(0)8037922869; E-mail: udoroelohor@yahoo.com

Received June 15, 2013; Accepted August 22, 2013; Published August 30, 2013

Citation: Oghenechavwuko UE, Saka GO, Adekunbi TK, Taiwo AC (2013) Effect of Processing on the Physico-Chemical Properties and Yield of Gari from Dried Chips. J Food Process Technol 4: 255. doi:10.4172/2157-7110.1000255

Copyright: (c) 2013 Oghenechavwuko UE, et al. This is an open-access article distributed under the terms of the Creative Commons Attribution License, which permits unrestricted use, distribution, and reproduction in any medium, provided the original author and source are credited. 
$70^{\circ} \mathrm{C}$, respectively for $48 \mathrm{~h}$ to a moisture content of about $10 \pm 2 \%$. The cassava chips obtained were allowed to cool, packed in polythene bags and sealed. Figure 1 shows the flow chart for the production of cassava chips.

\section{Preparation of gari from fresh cassava tubers}

The method of [9] was employed for the production of gari from fresh tubers which served as the control. Figure 2 shows the conventional method widely used in the processing of gari from fresh cassava tubers.

\section{Preparation of 4 day old liquor (4DOL)}

The method described by [4] was employed with slight modifications in preparing the four day old liquor. Fresh cassava tubers were peeled, washed and diced. $1 \mathrm{~kg}$ of peeled tubers was placed into 10 litres of water in a bucket, covered and allowed to stand for four days at room temperature. The liquor obtained is known as $4 \mathrm{DOL}$ and was used to initiate fermentation of chips.

\section{Preparation of gari from cassava chips}

The method of [8] was employed with some modifications. The dried cassava chips were coarsely milled using a Marlex Excella grinder (Marlex Appliances PVT, Daman) set at speed 1 for $15 \mathrm{~s}$. The coarsely milled chips were divided into two portions. The first portion of all the coarsely milled samples of chips were weighed into a sack and then immersed in 4-day old liquor (4DOL) for three days at room temperature ( $1 \mathrm{~kg}$ of milled chips in 5 litres of $4 \mathrm{DOL})$. At the end of soaking, the sacks were transferred to a laboratory hydraulic press ( 32 tons) for dewatering and for fermentation to continue for another 72 $\mathrm{h}$. The second portion was soaked in a similar manner in 4DOL for 4 days and pressed for two days. The implication of this was that all the samples were subjected to a total duration of 6 days of fermentation at room temperature $\left(28 \pm 2^{\circ} \mathrm{C}\right)$. The pressed cake obtained was sieved using a loosely knit raffia sieve (locally made) to disintegrate coarse lumps and remove large particles of cassava tubers in the mash The cassava mash obtained was dried with constant stirring over a heated wrought iron pan for several minutes until it was dried to about $10 \%$ moisture content. Adequate dryness was determined by tossing a

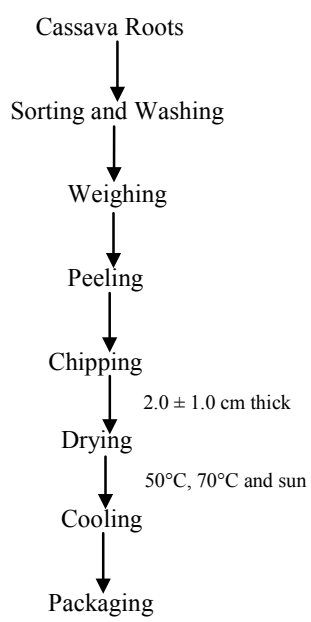

Source: FIIRO (2005)

Figure 1: Process Flow of Cassava Chips Production.

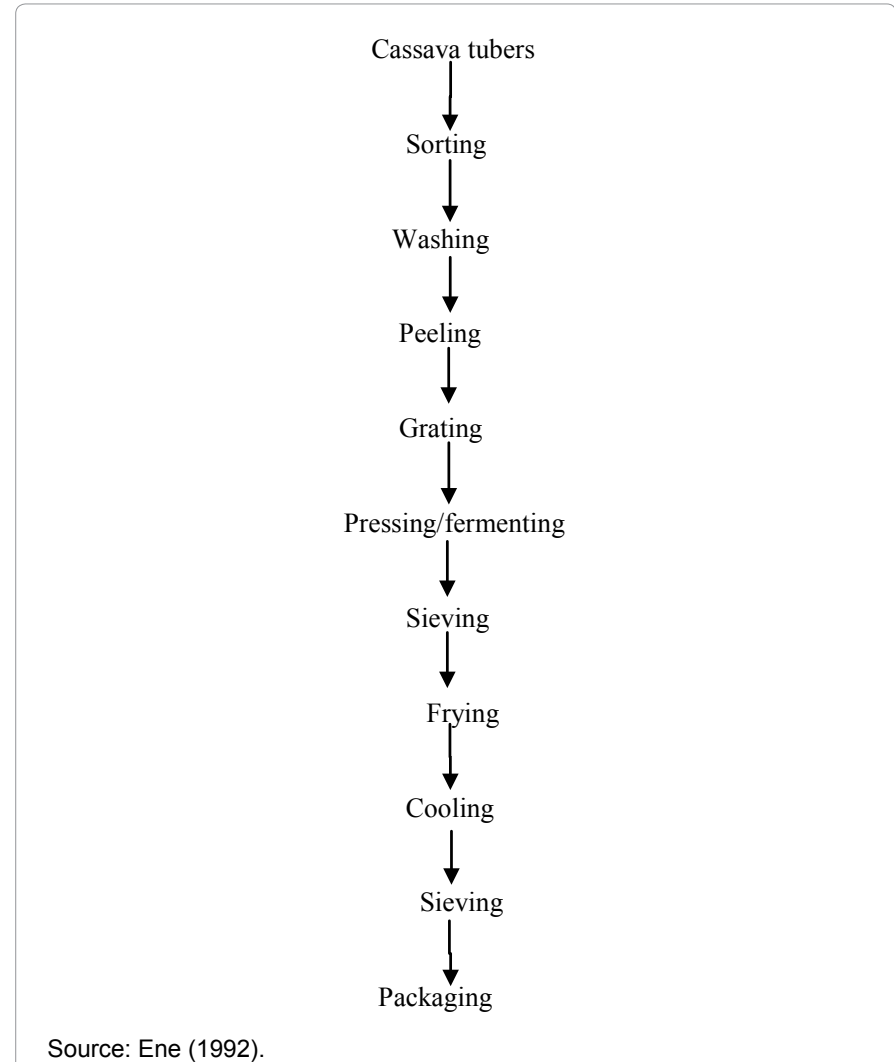

Figure 2: Flow Chart on the Processing of Gari.

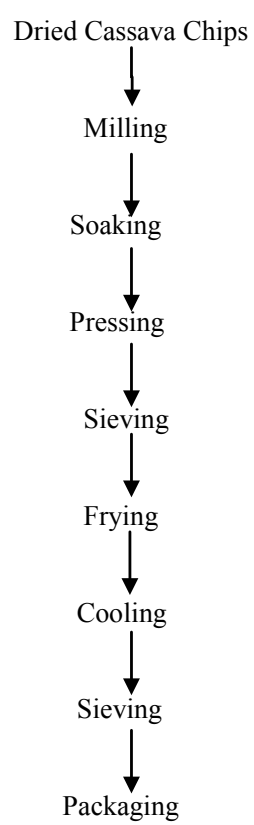

Source: Taiwo and Okesola (2009).

Figure 3: Process Flow of Gari Production from Dried Cassava Chips.

portion of the sample on a plate, the change in sound of the dropping sample indicated adequate dryness. The gari obtained was cooled, sieved again using a locally knit sieve for this purpose and stored in 
plastic bags. Figure 3 shows the flow chart for the production of gari from dried cassava chips.

\section{Physicochemical analysis}

The titratable acidity (TTA) and $\mathrm{pH}$ of the fermentation media (4DOL) were determined during soaking of the chips. The dried cassava chips were evaluated for their proximate, physicochemical, cyanide content and water absorption capacity.

\section{$\mathrm{pH}$ and total titratable acidity (TTA) of the fermenting medium}

The $\mathrm{pH}$ of the fermenting media was determined by taking a $10 \mathrm{ml}$ portion of the fermenting liquor daily and its $\mathrm{pH}$ determined using a HANNA pH meter (HANNA Instruments, model HI96107, Italy). The TTA (expressed as percentage lactic acid) of the fermenting media was determined by titrating $25 \mathrm{ml}$ of the fermenting medium against $0.1 \mathrm{~N}$ $\mathrm{NaOH}$. The TTA in each sample was determined as the product of the titre value and 0.09 which is the lactic acid factor $[6,10]$.

\section{Water absorption capacity of chips}

Water absorption capacity of the chips was determined by the method of [11] Taiwo et al. [11]. About $3 \mathrm{~g}$ of chips was placed in water $(1: 10 \mathrm{w} / \mathrm{v})$ in a glass beaker at room temperature. The chips were taken out of the water at $15 \mathrm{~min}$ interval, drained for $1 \mathrm{~min}$, weighed and returned to the water. Readings were taken at an hourly interval for another $6 \mathrm{~h}$. Water absorption was expressed as percentage increase of the sample weight.

\section{Proximate analysis}

Proximate composition of the dried cassava chips was determined according to standard [12] methods.

Moisture content: Moisture content was determined by the standard [12] official method by drying $5 \mathrm{~g}$ of samples to constant weight in an air-oven at $105^{\circ} \mathrm{C}$ for $6 \mathrm{hrs}$ and the result was expressed as the percentage difference in weight.

Protein content: Total protein content was determined using the Kjeldahl method [12]. Ground sample $(0.2 \mathrm{~g})$ was weighed into a Kjeldahl flask. Ten millimetre of concentrated sulphuric acid was added followed by one Kjeltec tablet. The mixture was digested to obtain a clear solution. The digested mixture was cooled and $75 \mathrm{ml}$ distilled water added followed by $50 \mathrm{ml}$ of $40 \%$ sodium hydroxide solution. The ammonia formed in the mixture was subsequently steam distilled into $25 \mathrm{ml}$ of $2 \%$ boric acid solution containing $0.5 \mathrm{ml}$ of indicator (bromocrisol green). The distillate collected was then titrated with $0.1 \mathrm{~N} \mathrm{HCl}$. Blank titration was carried out on the reagent and the nitrogen in the sample was calculated. The nitrogen content was multiplied by 6.25 to obtain crude protein content.

Crude fat: Crude fat was determined by the [12] method using soxhlet apparatus. Three grams of the ground sample was put into a thimble and extracted with n-hexane for about $6 \mathrm{~h}$. The solvent was removed from the extracted oil by evaporation. The oil was further dried in a hot-air oven at $100^{\circ} \mathrm{C}$ for $30 \mathrm{~min}$ to remove residual organic solvent and moisture. The flask containing the extracted oil was cooled in a dessicator and weighed. The quantity of oil obtained was expressed as percentage of the initial sample weight

Ash content: Ash content was determined by the official [12] method using a muffle furnace (Gallenkamp, England). Two grams of the sample was weighed into crucibles of known weight and placed in the muffle furnace chambers at $600^{\circ} \mathrm{C}$ until the samples turned to ashes. The crucibles were removed, cooled in a dessicator and weighed. Ash content was expressed as the percentage of the initial sample weight.

Crude fibre: Crude fibre was determined as described by [12] using 2 grams of ground sample which was extracted with n-hexane. This was transferred into a $1 \mathrm{~L}$ flask. About $200 \mathrm{ml}$ of $1.25 \%$ (v/v) boiling sulphuric acid was added and the flask was placed on a hot plate and boiled for $30 \mathrm{~min}$. The content was filtered and the residue was washed with $50-70 \mathrm{ml}$ of distilled water. The residue was removed and 200 $\mathrm{ml}$ boiling $1.25(\mathrm{w} / \mathrm{v}) \mathrm{NaOH}$ was added and boiled for $30 \mathrm{~min}$. The content was filtered and the residue was washed with distilled water. The residue was then transferred to an ashing dish and dried at $130^{\circ} \mathrm{C}$ for $2 \mathrm{~h}$, cooled in a dessicator and weighed. This was then ignited at $600^{\circ} \mathrm{C}$, cooled and reweighed. The difference in weight was taken as crude fibre.

Carbohydrate: Carbohydrate was determined by difference. Result was expressed in percentage.

\section{Cyanide content determination}

Hydrogen cyanide content was determined according to the procedure of [13] on the chips and gari samples. Ten grams of the ground sample was put into a Kjeldahl flask, approximately $200 \mathrm{ml}$ of distilled water was added and allowed to stand for 2-4 h. It was then steam distilled and about $150-160 \mathrm{ml}$ of distillate was collected over $2.5 \% \mathrm{NaOH}$ solution. Thereafter $8 \mathrm{ml}$ of $\mathrm{NH} \mathrm{OH}$ and $2 \mathrm{ml}$ of $5 \% \mathrm{KI}$ were added to $100 \mathrm{ml}$ of the distillate. Finally, the distillate was titrated against $0.02 \mathrm{~N} \mathrm{AgNO}_{3}$. Endpoint was faint but permanent turbidity was easily recognized against a black background.

HCN content was calculated using the equations below:

$$
\begin{aligned}
& \mathrm{HCN}(\mathrm{mg})=\frac{\mathrm{ml} \text { titrate }(\text { sample-blank })}{\mathrm{ml} \text { titrate blank }} \times 20 \times \frac{\text { Normality of } \mathrm{AgNO}_{3} \times 0.54}{0.02} \\
& \mathrm{HCN} \text { percent }=\frac{\mathrm{HCN}(\mathrm{mg})}{\mathrm{mg} \mathrm{sample}} \times 100 \% \\
& \text { Yield of } \text { gari }
\end{aligned}
$$

\section{Yield of gari}

The yield of gari processed was calculated on 3 bases. The method of [6] was used to calculate the percentage yield of gari from dried chips. The weight of gari obtained was divided by the weight (i.e. weight of the whole root, or weight of the mash or chips) and multiplied by 100 .

Whole root $=$ weight of fresh tuber before peeling

Mash $=$ moisture + chip weight

Chips $=$ weight of dried chips

\section{Statistical analysis}

All experiments were conducted in triplicate. Data reported are averages of three determinations. Analysis of variance (ANOVA) was performed and differences in mean values were evaluated using Duncan`s test at $\mathrm{p}<0.05$.

\section{Results}

\section{Proximate composition of chips}

The results of the proximate composition of chips dried under different drying conditions are presented in Table 1 . The moisture content of the chips varied between $10.24 \%$ and $12.11 \%$. Chips dried at $70^{\circ} \mathrm{C}$ in the oven had the least, $10.24 \%$, percentage moisture content. 
This could be attributed to the higher degree of heat applied to the chips during drying. The values obtained are lower than the recommended $13 \%$ for dried cassava chips [14]. The ash, protein, crude fat, crude fibre and carbohydrate contents of the different chips as shown in Table 1 were not significantly $(\mathrm{p}<0.05)$ different from each other. It could be deduced that the temperature $\left(50-70^{\circ} \mathrm{C}\right)$ and method (sun or oven) of drying the chips had no significant $(\mathrm{p}<0.05)$ effect on the chemical composition of the chips. The values of proximate composition of chips obtained in this study were comparable to the values (Moisture, $7.00 \%$; Ash, 1.80\%; Protein, 1.97\%; Crude Fat, 1.15\%; Crude Fibre, 2.24\% and Carbohydrate, $85.74 \%$ ) reported by [6].

\section{Physicochemical properties and cyanide content of chips}

The results of $\mathrm{pH}$, loose bulk density, packed bulk density and the cyanide content of dried cassava chips are presented in Table 2. The $\mathrm{pH}$ of the chips ranged between 5.8 and 6.7. The chips dried in the sun had the lowest $\mathrm{pH}$ value (5.8) and the chips dried at $50^{\circ} \mathrm{C}$ had the highest $\mathrm{pH}$ value (6.7). The $\mathrm{pH}$ values obtained in this study are comparable to the value (6.0) reported by [6] for dried cassava chips. These authors suggested that drying increased the concentration of acids in the tubers. The loose bulk density (LBD) and packed bulk density (PBD) were between 0.41 to 0.54 and 0.49 to $0.85\left(\mathrm{~g} / \mathrm{cm}^{3}\right)$, respectively. The $\mathrm{LBD}$ is expected to be less than the $\mathrm{PBD}$ because the latter, according to the method of [15], was tapped on a hard surface several times to ensure compactness of the chips while the former was not tapped and contained larger air spaces. The samples dried in the oven at $70^{\circ} \mathrm{C}$ had the highest bulk densities and chips dried at $50^{\circ} \mathrm{C}$ in the oven had the least bulk densities. The percentage moisture content (Table 1) may have influenced the bulk densities of the samples. High bulk densities imply reduced volume and a larger quantity (weight) of chips can be packaged or transported per volume of space. This is one important reason for the conversion of fresh cassava tubers to dried chips $[2,16,17]$. The values obtained in this study are higher than the bulk density $\left(0.056 \mathrm{~g} / \mathrm{cm}^{3}\right)$ of potato chips reported by [18].

The cyanide content of the dried cassava chips ranged between $58.26 \pm 3.51$ and $69.83 \pm 0.94 \mathrm{mg} / 100 \mathrm{~g}$. Sundried chips had the least $(5.83 \pm 0.35 \mathrm{mg} / \mathrm{kg})$ cyanide content and $70^{\circ} \mathrm{C}$ oven dried chips had the highest $(6.98 \pm 0.09 \mathrm{mg} / \mathrm{kg})$ cyanide content. This suggests that sun drying eliminated more cyanide from the fresh tubers than oven drying at $50^{\circ} \mathrm{C}$ and $70^{\circ} \mathrm{C}$. This may be attributed to the longer time (3-4 days) it took the chips to dry in the sun and the shorter time (1-2 days) it took the chips to dry in the oven.

Earlier studies have shown that the time and temperature of drying amongst other factors influence the rate of cyanide elimination in cassava tubers. Sun drying has been reported to be more effective than oven drying as it allows longer contact between linamarase, the glycosides and water, an essential substrate for linamarase, for a longer time in the tubers $[19,20]$. The results in this study agree with an earlier study by [21] which revealed that cyanide retention is dependent on the drying temperature of the chips stating that more cyanide was retained during drying at $70^{\circ} \mathrm{C}$ than at $50^{\circ} \mathrm{C}$. Faster drying reduced the contact time between linamarase and glycosides. It can therefore be deduced that the variation in time of drying and the temperature had a significant effect on the cyanide content of the dried chips. Although chips are mostly processed further before they are consumed, the cyanide content of chips will provide processors with information on the intensity of processing required before the end product will be considered safe for human consumption.

\section{Water absorption capacity of chips}

Water absorption of dried cassava chips at room temperature as influenced by the soaking time is shown in Figure 4 . The water absorption of chips varied between 28.21 and $98.81 \%$. Chips dried at $50^{\circ} \mathrm{C}$ exhibited the highest water absorption capacity after $6 \mathrm{~h}$ of soaking. Water absorption of the chips increased with increase in time, however a decrease was observed for chips oven dried at $70^{\circ} \mathrm{C}$ after the fifth hour. This may be due to easier disintegration of the chips caused by excess intake of water. Rapid uptake of water was observed in the first one hour (about $40 \%$ of the total uptake), followed by a gradual increase in water absorption for the remaining five hours in all samples of chips. It was observed that the water absorption of sundried chips was higher than the oven dried chips for the first four hours after which the water absorption of the oven dried chips increased above that of the sun dried chips. In a similar study by [4], the water absorption capacity (above 100\%) for chips dried in the oven at $35^{\circ} \mathrm{C}$ was higher than that of sundried chips (below 100\%) all through the six hours of soaking. This implies that the temperature at which chips are dried affect their rate of water intake and further influence rehydration during processing.

\section{$\mathrm{pH}$ and TTA of fermenting medium (4DOL)}

The change in $\mathrm{pH}$ and total titratable acidity (TTA) of the fermenting medium at room temperature of cassava chips dried under different conditions is presented in Table 3. The breakdown of starch in fresh cassava tubers by cassava bacterium Corynebacterium manihot to simple sugars and its subsequent fermentation to produce lactic and formic acids have been reported to be responsible for the initial drop in $\mathrm{pH}$ of the fermenting medium [22] hence the initial $\mathrm{pH}$ of 4.65 of the fermenting (4DOL) medium. As fermentation time increased, the $\mathrm{pH}$ of the fermenting media decreased and the decrease was observed throughout the steeping period of $96 \mathrm{~h}$. There was no significant $(\mathrm{p}<0.05)$ difference in the $\mathrm{pH}$ values recorded for the fermenting media of the different chips. This implies that the drying temperatures did not have any significant $(\mathrm{p}<0.05)$ effect on the $\mathrm{pH}$ of the fermenting medium that is temperature of drying the chips did not alter the properties of the chips that will affect its reaction later. The observed decrease in $\mathrm{pH}$ could be attributed to further activities of cassava microbes on the substrate (starch in the dried chips) and the low $\mathrm{pH}$ further encouraged the growth of a fungus Geotrichum candidum which brought about further acidification [23].

The titratable acidity varied from 0.09 at $0 \mathrm{~h}$ to 0.68 at $96 \mathrm{~h}$. The titratable acidity (TTA) results also followed a similar pattern with that of change in $\mathrm{pH}$. The TTA increased with increasing time of steeping but the increase was however not significant $(p<0.05)$ among the samples or within the time of fermentation. The increase in TTA further suggests that organic acids were produced during fermentation of cassava chips using 4DOL and this was probably due mainly to the increased activities of the fermenting microorganisms native to fresh cassava and other organisms present at ambient temperature under which the fermentation was carried out.

\section{Effect of processing on gari yield}

The yield of gari from different processing conditions is shown in Table 4. The yield calculated based on the weight of the whole root, mash and chips ranged from 17.72-32.77\%, 22.67-41.91 and 70.24$78.60 \%$, respectively. The yield of the control sample calculated based on the weight of the whole root (32.77\%) and mash (41.9\%) was higher than that of the experimental samples, this could be attributed to the 
Citation: Oghenechavwuko UE, Saka GO, Adekunbi TK, Taiwo AC (2013) Effect of Processing on the Physico-Chemical Properties and Yield of Gari from Dried Chips. J Food Process Technol 4: 255. doi:10.4172/2157-7110.1000255

Page 5 of 6

\begin{tabular}{|c|c|c|c|c|c|c|}
\hline Sample & Moisture & Ash & Protein & Crude fat & Crude Fibre & Carbohydrate \\
\hline SD & $11.90 \pm 0.10^{b}$ & $1.53 \pm 0.46^{a}$ & $1.30 \pm 0.01^{a}$ & $1.34 \pm 0.15^{\mathrm{a}}$ & $2.58 \pm 0.15^{a}$ & $81.37 \pm 0.86^{a b}$ \\
\hline OV50 & $12.11 \pm 0.33^{b}$ & $1.87 \pm 0.28^{a}$ & $2.56 \pm 0.60^{b}$ & $1.47 \pm 0.17^{a}$ & $2.79 \pm 0.33^{a}$ & $79.21 \pm 1.14^{a}$ \\
\hline OV70 & $10.24 \pm 0.05^{a}$ & $2.06 \pm 0.07^{a}$ & $1.51 \pm 0.29^{\mathrm{ab}}$ & $1.40 \pm 0.01^{a}$ & $2.72 \pm 0.16^{a}$ & $82.08 \pm 0.00^{b}$ \\
\hline
\end{tabular}

$\mathrm{SD}$, Sun dried chips

OV50, chips dried in the oven at $50^{\circ} \mathrm{C}$

OV70, chips dried in the oven at $70^{\circ} \mathrm{C}$

Values with similar letters in the same column are not significantly $(p<0.05)$ different.

Table 1: Proximate composition of chips.

\begin{tabular}{|c|c|c|c|}
\hline Samples & pH & LBD(g/ml) & PBD(g/ml) \\
\hline SD & $5.8 \pm 0.00$ & $0.46 \pm 0.04^{\text {ab }}$ & $0.51 \pm 0.06^{\mathrm{a}}$ \\
\hline OV50 & $6.7 \pm 0.00$ & $0.41 \pm 0.2^{\mathrm{a}}$ & $0.49 \pm 0.05^{\mathrm{a}}$ \\
\hline OV70 & $6.2 \pm 0.00$ & $0.54 \pm 0.03^{\mathrm{b}}$ & $0.85 \pm 0.04^{\mathrm{b}}$ \\
\hline
\end{tabular}

$\mathrm{SD}$, Sun dried chips

OV50, chips dried in the oven at $50^{\circ} \mathrm{C}$

OV70, chips dried in the oven at $70^{\circ} \mathrm{C}$

LBD, Loose bulk density

PBD, Packed bulk density

Values with similar letters in the same column are not significantly $(p<0.05)$ different.

Table 2: Physicochemical properties and cyanide content of chips.

\begin{tabular}{|c|c|c|c|c|c|c|}
\hline & & $\mathrm{pH}$ & & & TTA & \\
\hline Time(hr) & SD & OV50 & OV70 & SD & OV50 & OV70 \\
\hline 0 & $4.65 \pm 0.07^{\mathrm{a}}$ & $4.65 \pm 0.07^{a}$ & $4.65 \pm 0.07^{\mathrm{a}}$ & $0.09 \pm 0.01^{a}$ & $0.09 \pm 0.01^{a}$ & $0.09 \pm 0.01^{a}$ \\
\hline 24 & $4.35 \pm 0.07^{\mathrm{a}}$ & $4.25 \pm 0.07^{\mathrm{a}}$ & $4.35 \pm 0.07^{\mathrm{a}}$ & $0.45 \pm 0.02^{a}$ & $0.50 \pm 0.01^{b}$ & $0.41 \pm 0.00^{\mathrm{a}}$ \\
\hline 48 & $3.95 \pm 0.07^{\mathrm{a}}$ & $4.00 \pm 0.00^{\mathrm{a}}$ & $4.00 \pm 0.00^{\mathrm{a}}$ & $0.59 \pm 0.01^{a}$ & $0.56 \pm 0.02^{\mathrm{a}}$ & $0.55 \pm 0.01^{a}$ \\
\hline 72 & $3.95 \pm 0.07^{\mathrm{a}}$ & $3.90 \pm 0.00^{\mathrm{a}}$ & $3.95 \pm 0.07^{a}$ & $0.64 \pm 0.01^{c}$ & $0.60 \pm 0.01^{b}$ & $0.55 \pm 0.01^{a}$ \\
\hline 96 & $3.90 \pm 0.00^{\mathrm{a}}$ & $3.90 \pm 0.00^{\mathrm{a}}$ & $3.95 \pm 0.07^{\mathrm{a}}$ & $0.68 \pm 0.00^{c}$ & $0.63 \pm 0.01^{b}$ & $0.60 \pm 0.00^{a}$ \\
\hline
\end{tabular}

$\mathrm{SD}$, Sun dried chips

OV50, chips dried in the oven at $50^{\circ} \mathrm{C}$

OV70, chips dried in the oven at $70^{\circ} \mathrm{C}$

Values with similar letters in the same row are not significantly different.

Table 3: $\mathrm{pH}$ and TTA of fermenting medium (4DOL).

\begin{tabular}{|c|c|c|c|}
\hline Yield (\%) & Whole root & Mash & Chips \\
\hline SD2 & $18.14 \pm 0.05^{\mathrm{a}}$ & $23.20 \pm 2.68^{\mathrm{a}}$ \\
\hline SD3 & $19.52 \pm 0.03^{\mathrm{bc}}$ & $24.97 \pm 1.14^{\mathrm{a}}$ \\
\hline OV50.2 & $17.72 \pm 0.12^{\mathrm{a}}$ & $22.67 \pm 3.05^{\mathrm{a}}$ & $71.90 \pm 0.85^{\mathrm{a}}$ \\
\hline OV50.3 & $19.04 \pm 0.07^{\mathrm{b}}$ & $24.35 \pm 4.16^{\mathrm{a}}$ & $77.37 \pm 1.01^{\mathrm{bc}}$ \\
\hline OV70.2 & $18.14 \pm 0.10^{\mathrm{a}}$ & $23.20 \pm 0.09^{\mathrm{a}}$ & $75.24 \pm 0.76^{\mathrm{a}}$ \\
\hline OV70.3 & $19.83 \pm 1.01^{\mathrm{c}}$ & $25.36 \pm 2.21^{\mathrm{a}}$ & $71.89 \pm 0.10^{\mathrm{a}}$ \\
\hline Control & $32.77 \pm 0.08^{\mathrm{d}}$ & $32.77 \pm 0.08^{\mathrm{d}}$ \\
\hline
\end{tabular}

SD2, Sun dried chips (soaked three days and pressed three days)

SD3, Sun dried chips (soaked four days and pressed two days)

OV 50.2 , Oven dried chips at $50^{\circ} \mathrm{C}$ (soaked three days and pressed three days)

OV 50.3 , Oven dried chips at $50^{\circ} \mathrm{C}$ (soaked four days and pressed two days)

OV 70.2 , Oven dried chips at $70^{\circ} \mathrm{C}$ (soaked three days and pressed three days)

OV 70.3 , Oven dried chips at $70^{\circ} \mathrm{C}$ (soaked four days and pressed two days)

Control, Processed from fresh cassava tubers

Whole root $=$ peel + moisture + chip weight

Mash $=$ moisture + chip weight

Chips = weight of dried chip

Table 4: Percentage yield of gari samples.

removal of moisture in the chips. It was observed that the yield increased with increase in soaking period irrespective of the drying temperature of the chips. This could be attributed to the greater softening/retting of the chips due to longer steeping in the fermenting medium (4DOL) hence during sieving, more mash was realized. The yield (17.72$19.83 \%$ ) of the experimental samples calculated based on the weight of the whole roots is comparable to the findings of [8] who reported gari yield between $18-23 \%$ under varying conditions. Similarly, the yield (32.77\%) of gari from fresh root is comparable to the value $(31.2 \%)$ reported by [24]. Also, the yield of $22.67-25.36 \%$ for the experimental samples is within the range $20.9-29.6 \%$ of yield reported by [24] for gari processed from cassava tubers stored for 7-14 days. The yield (70.24$78.60 \%$ ) of gari from chips reported in this study were comparable to those reported by [6] who seeded dried cassava chips with $0-20 \%$ fresh mash to obtain a yield of $68.42-85 \%$. The finding in this study suggests that the period of soaking significantly influenced yield more than the drying temperatures. 


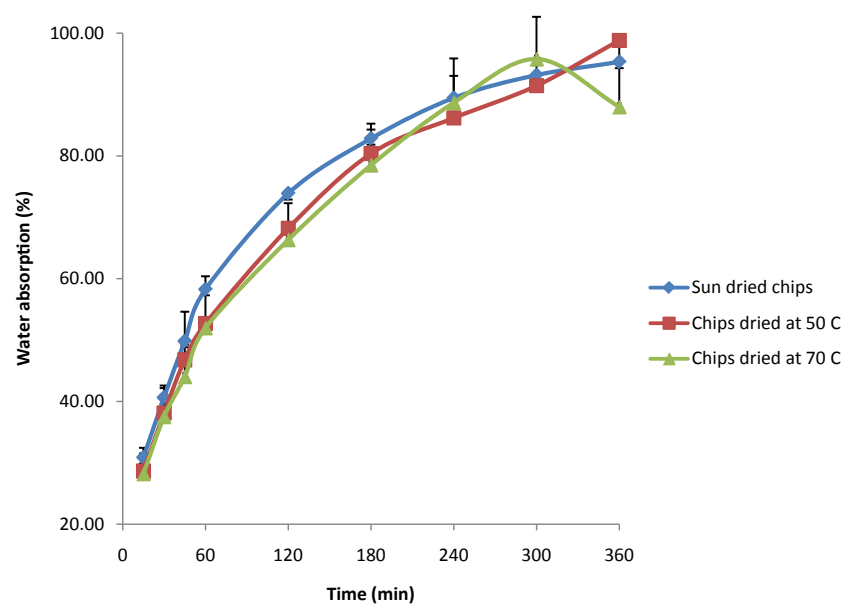

Figure 4: Water absorption of chips as a function of time at room temperature.

\section{Conclusion}

The drying temperatures and times in this study were adequate to produce chips with moisture content that meet the standard storage requirement for chips. The drying temperatures had no significant $(\mathrm{p}<0.05)$ effect on the proximate composition and water absorption capacity of the chips. Chips dried under these conditions can be utilized for gari production by steeping in $4 \mathrm{DOL}$ at room temperature. The yield of gari from dried chips increased with soaking/fermentation time and the values obtained in this study compared favourably with those from previous studies. The processing conditions in this study are adequate to give good yield of gari from dried cassava chips.

\section{Acknowledgement}

The authors are grateful to Obafemi Awolowo University Research Committee for funding the research through project No: 11812AMX. The first autho acknowledges the Carnegie Corporation, New York and the Scholarship Board of Delta State Government, Nigeria for cash scholarship awards received in the course of this work.

\section{References}

1. Eggleston G, Bokanga M, Jean YW (1992) Traditional African methods for cassava processing and utilization and research needs. In: MO Akoroda \& OB Arene (Eds.), Proceedings 4th Triennial Symposium, International Society for Tropical Root Crops- Africa Branch, (pp.3-6). Kinshasa Zaire, December 5-8, 1989.

2. Ihekoronye Al, Ngoddy PO (1985) Integrated food science and technology for the tropics. Macmillan, London. Pp 267-275.

3. Federal Institute of Industrial Research (2005) Cassava processing. FIIRO, Oshodi, Nigeria.

4. Irinkoyenikan OA, Taiwo KA, Gbadamosi SO, Akanbi CT (2008) Studies of fufu Production from Cassava Chips, Proceedings of Humboldt - Kolleg Held At The Obafemi Awolowo University, Ile-lfe, Nigeria, Pp 117-132.

5. Ikunjelola AV, Omosuli SV (2009) Dehydrated Cassava Chips Utilization in Starch and "Garri" Production. Advanced Materials Research 62: 203-207.

6. Oluwole OB, Olatunji OO, Odunfa SA (2004) A Process Technology for Conversion of Dried Cassava Chips into "Gari". Nigerian Food Journal 22: 6577.
7. Onabolu AO, Oluwole OSA, Rosling H, Bokanga M (2002) Processing factors affecting the levels of residual cyanohydrins in gari. J Sci Food Agr 82: 966-969.

8. Taiwo KA, Okesola CO (2009) A Study of Some Processing Factors on the Production of Gari (A Fermented Product) from Dehydrated Cassava Chips. Annual Meeting, Nashville, USA.

9. Ene LSO (1992) Prospects for processing and utilization of root and tuber crops in Africa. Proceedings 4th Triennial Symposium, International Society for Tropical Root Crops- Africa Branch, (23-32). Kinshasa Zaire, December 5-8, 1989.

10. Okoro CC (2007) Effect of process modification on the physio-chemical and sensory quality of fufu-flour and dough. African Journal of Biotechnology 6 : 1949-1953.

11. Taiwo KA, Akanbi CT, Ajibola OO (1994) Effect of soaking conditions on the water absorption and texture of two cowpea varieties (Vigna unguiculata). Nigerian Food Journal 12: 11-18.

12. AOAC (1990) Association of Official Analytical Chemists. Official methods of Analysis, 13th edition. Washington DC, USA.

13. Sudarmadji S, Haryono B, Suhardi (1997) Prosedur analisa untuk bahan makanen dan pertanian. Edisi Ketiga: Liberty. Yogyakarta pp 138.

14. FAO (2006) Processing of Roots and Tubers In: Storage and Processing of Roots amd Tubers: Agriculture and Consumer Protection paper.

15. Okezie BO, Bello AB (1988) Physicochemical and Functional Properties of Winged Bean Flour and Isolate Compared with Soy Isolate. J Food Sci 53: 450-454.

16. Singh RP, Heldman DR (2008) Introduction to Food Engineering. Academic press Inc. P. 258-262.

17. Taiwo KA (2006) Utilization Potentials of Cassava in Nigeria: The Domestic and Industrial Products. Food Rev Int 22: 29-42.

18. Robertson GL (2013) Food Packaging: Principles and Practice. 3rd edition CRC Press, USA. P. 335.

19. Balagopalan C (1988) Cassava nutrition and toxicity, In: Cassava in Food Feed and Industry, RJ Hillocks, JM Tresh, AC Belloti, eds. CRC Press. Boca Raton, FL, pp 13-16.

20. Padmaja G (1995) Cyanide detoxification in cassava for food and feed uses Crit Rev Food Sci Nutr 35: 299-339.

21. Nambisan B, Sundaresan S (1985) Effect of processing on the cyanoglucoside content of cassava. J Sci Food Agr 36: 1197-1203

22. Amund OO, Ogunsina OA (1987) Extracellular amylase production by cassavafermenting bacteria. Journal of Industrial Microbiology 2: 123-127.

23. Kimaryo VM, Massawe GA, Olasupo NA, Hozaphel WH (2000) The use of a starter culture in the fermentation of cassava for the production of "Kivunde", a traditional Tanzanian food product. Int J Food Microbiol 56: 179-190.

24. Karim OR, Fasasi OS, Oyeyinka SA (2009) Gari Yield and Chemical Composition of Cassava Roots Stored Using Traditional Methods. Pakistan Journal of Nutrition 8: 1830-1833. 